\title{
GUYANAGASTER, A NEW WOOD-DECAYING SEQUESTRATE fungal genus related to Armillaria (Physalacriaceae, Agaricales, Basidiomycota) ${ }^{1}$
}

\author{
Terry W. Henkel ${ }^{2,5}$, Matthew E. Smith ${ }^{3}$, and M. Catherine Aime ${ }^{4}$ \\ ${ }^{2}$ Department of Biological Sciences, Humboldt State University, Arcata, California 95521 USA; ${ }^{3}$ Department of Biology, \\ Duke University, Durham, North Carolina 27708 USA; and ${ }^{4}$ Department of Plant Pathology and Crop Physiology, \\ Louisiana State University Agricultural Center, Baton Rouge, Louisiana 70803 USA
}

- Premise of the study: Sequestrate basidiomycete fungi (e.g. "gasteromycetes") have foregone ballistospory and evolved alternative, often elaborate mechanisms of basidiospore dispersal with highly altered basidioma morphology. Sequestrate fungi have independently evolved in numerous Agaricomycete lineages, confounding taxonomic arrangements of these fungi for decades. Understanding the multiple origins and taxonomic affinities of sequestrate fungi provides insight into the evolutionary forces that can drastically alter basidioma morphology. In the neotropical rainforests of the Guiana Shield, we encountered a remarkable sequestrate fungus fruiting directly on decaying hardwood roots. The fungus' singular combination of traits include a wood-decaying habit; black, verrucose peridium; reduced stipe; and gelatinized basidiospore mass.

- Methods: Guyanagaster necrorhiza gen. et sp. nov. is described. Macro- and micromorphological characters were assessed and compared to most similar taxa. To determine the phylogenetic affinities of the fungus, DNA sequence data were obtained for the $18 \mathrm{~S}$, ITS, and $28 \mathrm{~S}$ rDNA, $R B P 2$, and $E F 1 \alpha$ regions and subjected to single- and multi-gene analyses. DNA sequences from fungal vegetative organs growing on decaying woody roots confirmed the wood-inhabiting lifestyle of Guyanagaster.

- Key results: Guyanagaster is morphologically unique among sequestrate fungi worldwide. Phylogenetic evidence places Guyanagaster in close relation to the wood-decaying mushroom genus Armillaria in the Physalacriaceae (Agaricales, Agaricomycetes, Basidiomycota).

- Conclusions: Guyanagaster represents an independently evolved sequestrate form within the Physalacriaceae. Although molecular data confirm that Guyanagaster is closely related to Armillaria, the unusual features of this fungus suggest a case of radically divergent morphological evolution.

Key words: Agaricomycetes; basidiomycetes; fungal taxonomy; gasteromycete syndrome; Guyana; neotropics; rDNA systematics; sequestrate fungi; statismosporic fungi.

Within the Basidiomycota, "gasteromycetes" comprise a diverse, artificial assemblage of puffballs, earthstars, false earthstars, earthballs, bird's nest and cannonball fungi, stinkhorns, secotioid agarics and boletes, and false truffles (Miller and Miller, 1988). The basidiospores of these fungi mature within their basidiomata, not on exposed hymenial surfaces (i.e., they are "sequestrate"), and are ultimately dispersed via mechanisms other than direct forceable discharge from basidia into the airstream. Sequestrate basidioma morphologies adapted for dispersal via rain splash, animal mycophagy, forceable discharge of peridioles, physical weathering, or a bellows mechanism represent some of most dramatic evolutionary experiments in the Fungi

1 Manuscript received 9 March 2010; revision accepted 21 June 2010.

The authors thank the following the sources for funding: the National Geographic Society's Committee for Research and Exploration and NSF DEB-0918591 (T.W.H.), Harvard University Herbaria (M.E.S.), W. K. Smith for a field research gift, and NSF DEB-0732968 (M.C.A.). Field assistance in Guyana was provided by M. Chin, C. Andrew, V. Joseph, F. Edmond, and L. Edmond. Research permits were granted by the Guyana Environmental Protection Agency. The authors also thank D. Pfister for use of laboratory facilities, R. Kaur for technical assistance, C. Feuillet for the Latin diagnoses, and two anonymous reviewers for constructive critical comments. This paper is number 167 in the Smithsonian Institution's Biological Diversity of the Guiana Shield Program publication series.

5 Author for correspondence (e-mail: twh5@ humboldt.edu)

doi:10.3732/ajb.1000097
(Ingold, 1965; Kendrick, 1992). The sequestrate Basidiomycota were traditionally treated as a cohesive taxonomic unit (e.g., class Gasteromycetes) with the assumption that ballistospory was lost rarely in the evolutionary history of fungi and that the advent of hymenial enclosure was rare (e.g., Coker and Couch, 1928). Alternatively, it had been suggested that the sequestrate state was ancestral in hymenomycetes before the evolution of ballistospory (e.g., Singer, 1971). Other early authors regarded sequestrate fungi as a polyphyletic group based on morphological and developmental evidence (e.g., Reijnders, 1963; Heim, 1971).

Molecular systematics studies of Agaricomycetes have since revealed that sequestrate fungi have independently evolved many times within the class and that new sequestrate taxa are being discovered in family or genus-level lineages previously thought to be entirely nonsequestrate (Bruns et al., 1989; Mueller and Pine, 1994; Hibbett et al., 1997; Miller et al., 2000; Miller and Aime, 2001; Peintner et al., 2001; Binder et al., 2006). Some sequestrate fungi represent recent, isolated evolutionary events that led to one or a few sequestrate species within a clade of nonsequestrate relatives (e.g., Kretzer and Bruns, 1997; Martin et al., 1999; Smith et al., 2006), whereas other sequestrate clades of earlier origin have speciated and radiated across the globe (e.g., Grubisha et al., 2002; Binder and Hibbett, 2006; Hosaka et al., 2006). Additionally, understanding of the multiple origins and taxonomic affinities of sequestrate fungi provides insight into the evolutionary forces that can 
drastically alter basidioma form and function. (Thiers, 1984; Kretzer and Bruns, 1997; Reijnders, 2000; Trappe and Claridge, 2005; Albee-Scott, 2007)

Traditional classifications of sequestrate basidiomycete fungi relied on overall basidioma form as well as morphology of the peridium, basidiospores, and basidia (Miller and Miller, 1988; Trappe et al., 2009). Natural classifications aligning sequestrates with their nonsequestrate relatives have been problematic because many sequestrate taxa have reduced or unusual features that obscure phylogenetic inference. Sequestrate fungi often lack a stipe, their basidia may be atypically shaped and/or disappear at maturity, peridial structures may be poorly differentiated, and their basidiospores are usually highly ornamented in comparison to those of their closest nonsequestrate relatives (Trappe et al., 2009). In addition, because many sequestrate fungi fruit below ground, they are infrequently collected and relatively understudied (Montecchi and Sarasini, 2001; Trappe et al., 2009).

Tropical sequestrate fungi are poorly known. For example, Mueller et al. (2007) estimated that ca. 30 species of hypogeous sequestrate taxa are currently described from the neotropics with ca. 200 species remaining unknown to science. Recent studies in the Guiana Shield region of northeastern South America have revealed a diverse assemblage of sequestrate fungi in forests dominated by ectomycorrhizal Dicymbe spp. (Fabaceae subfam. Caesalpinioideae). They are from divergent basidiomycete orders, including Agaricales, Boletales, Geastrales, Hysterangiales, and Phallales, as well as the ascomycetous Eurotiales (T. W. Henkel, M. C. Aime, M. E. Smith; S. L. Miller, University of Wyoming; M. A. Castellano, Oregon State University; unpublished data; Miller et al., 2001; Aime and Henkel, 2008).

Here we describe Guyanagaster necrorhiza gen. et sp. nov. from the Pakaraima Mountains of Guyana, using morphological, molecular, and ecological data. This extraordinary new fungus is the only sequestrate taxon known with close affinities to the root parasitic, lamellate mushroom genus Armillaria (Fr.) Staude (Physalacriaceae, Agaricales, Agaricomycetes, Agaricomycotina, Basidiomycota), a genus of immense economic and ecological importance worldwide (Termorshuizen, 2000). While these affinities are corroborated by the root-decaying habit of G. necrorhiza, its sequestrate form suggests a case of extreme divergence in fruiting morphology from Armillaria, the evolutionary pressures for which are currently unknown.

\section{MATERIALS AND METHODS}

Collecting and morphological analyses - Collecting expeditions were conducted during the rainy seasons of May-July of 2001-2003, 2008-2010 and December 2009 in the Upper Potaro River Basin in the west-central Pakaraima Mountains of Guyana. Fungi were collected within a $15-\mathrm{km}$ radius of a previously established base camp $\left(5^{\circ} 18^{\prime} 04.8^{\prime \prime} \mathrm{N}, 59^{\circ} 54^{\prime} 40.4^{\prime \prime} \mathrm{W}\right)$ in forests dominated by Dicymbe corymbosa Spruce ex Benth. and D. altsonii Sandw. (Henkel, 2003). Basidiomata of the black, truffle-like fungus were examined in the field for their fruiting habit and substratum relationships and described for their fresh morphological characteristics. Color was subjectively described and recorded according to Kornerup and Wanscher (1978) with corresponding color plates noted in parentheses (e.g., 3C4). Macrochemical spot tests followed those of Singer (1986). To elucidate the nutritional habit of the fungus, we collected $0.5-3 \mathrm{~cm}$ diameter small roots of $D$. corymbosa that were found in the vicinity of the basidiomata. We selected roots with attached hyphal cords, mycelial fans in the cambium, and white rot decay. Basidiomata, hyphal cords, and mycelial fans were field-dried with silica gel for molecular analyses (Miller et al., 2002). Additionally, mature basidiomata exhibiting arthropod excavation channels were collected and examined.
Micromorphological features of fresh basidiomata were examined in the field with an EPOI microscope and on dried specimens in the laboratory using an Olympus BX51 microscope with bright field and phase contrast optics. Dried specimens were sectioned by hand or on a freezing microtome and mounted in water, $3 \% \mathrm{KOH}$, Melzer's reagent (Largent et al., 1977), or stained with $1 \%$ aqueous congo red or cotton blue. Twenty randomly selected basidiospores were measured under a $100 \times$ objective. Length/width $Q$ values for basidiospores are reported as $Q_{\mathrm{r}}$ (range of $Q$ values over 20 basidiospores measured) and $Q_{\mathrm{m}}$ (mean of $Q$ values $\pm \mathrm{SD}$ ). Images were digitally captured using an Olympus XC50 digital camera. Specimens were deposited in the following herbaria: BRG, HSU, FH, NY, LSUM, and DUKE (Holmgren et al., 1990; Appendix 1). Voucher specimens of vegetative organs and wood decay are maintained at Humboldt State University.

Molecular methods and phylogenetic analyses-Fungal tissues from basidiomata, hyphal cords, and mycelial fans were placed in separate microcentrifuge tubes and ground with micropestles. DNA was extracted by a modified CTAB method (Gardes and Bruns, 1993) or with the Wizard Genomic DNA Purification Kit on field tissue samples stored in $600 \mu \mathrm{L}$ of Nuclei Lysis Solution and extracted using the manufacturer's protocols (Promega, Madison, Wisconsin, USA). PCR reactions were performed with published primers and according to standard protocols. For basidiomata, the ITS and the first ca. 1000 bp of the large subunit ribosomal (28S) DNA were amplified with several primer combinations: ITS1F/ITS4B (Gardes and Bruns, 1993), ITS1F/LR3 (Smith et al., 2007), LROR/LR5F (Tedersoo et al., 2008), and LSU4B/LR6 (Aime and Phillips-Mora, 2005). Approximately $1100 \mathrm{bp}$ of the small ribosomal subunit (18S) was amplified with primers NS3 and NS8 (White et al., 1990). The variable region between domains 6 and 7 of the $R P B 2$ gene was amplified with primers RPB2-6F and RPB2-7R (http://faculty.washington.edu/ benhall/; Matheny, 2005). DNA sequences of the Elongation Factor 1-alpha $(E F 1 \alpha)$ gene were amplified using primers EF1-df and EF1-2218r (AFTOL website: http://www.aftol.org/primers.php; Rehner and Buckley, 2005). For an individual hyphal cord and mycelial fan, the ITS region was amplified to allow comparison with basidioma ITS sequences.

PCR products were visualized on $1.5 \%$ agarose gels stained with SYBR Green I (Molecular Probes, Eugene, Oregon, USA). Successful amplicons were cleaned with ExoSAP-IT (USB Corp., Cleveland, Ohio, USA). Bidirectional sequencing was performed with the described primers using the Big Dye Sequencing Kit v.3.1 (Applied Biosystems, Foster City, California, USA) on an ABI13730xl capillary sequencer (Applied Biosystems). Sequences were edited with the program Sequencher v.4.1 (Gene Codes, Ann Arbor, Michigan, USA).

Initial blastn (http://blast.ncbi.nlm.nih.gov/Blast.cgi) analyses of the $28 \mathrm{~S}$ sequence data indicated that our fungus had close affinities with Armillaria within the Physalacriaceae (Agaricales, Agaricomycetes, Basidiomycota). Subsequently, data sets were constructed from sequences downloaded from GenBank as follows: (1) a five-gene data set (ITS, 28S, $18 \mathrm{~S}, R P B 2$, and $E F 1 \alpha$ ), consisting of exemplars from several genera of the Physalacriaceae with Agaricales outgroups selected from the sister families Schizophyllaceae and Lachnellaceae, and the more distant families Cyphellaceae and Marasmiaceae, based on data shown in Matheny et al. (2006; Appendix 1). Because varying sequence availability limited the number of generic representatives that could be included in the multigene data set, two more taxon-rich data sets were constructed using (2) the $28 \mathrm{~S}$ rDNA only and (3) the $E F 1 \alpha$ gene only. The $28 \mathrm{~S}$ sequence data set contained the widest array of taxa in the Physalacriaceae, including members of the genera Cribbea, Mycotribulus, Rhodotus, Strobilurus, and Oudemansiella as well as additional species of Armillaria. The EFla data set contained $G$. necrorhiza, nine species of Armillaria, and one species each of Flammulina, Schizophyllum, and Oudemansiella.

Sequence alignments were constructed manually in the program Se-Al v2.0a11 (Andrew Rambaut, Department of Zoology, University of Oxford, UK; http://evolve.zoo.ox.ac.uk/). Ends were trimmed, and regions too variable to be reliably aligned were excluded from final analyses; adjustments were as follows: $28 \mathrm{~S}$ : 39 of 958 total bp were removed; ITS: only $166 \mathrm{bp}$ containing the $5.8 \mathrm{~S}$ region were included; $18 \mathrm{~S}$ : the taxon Xerula radicata contained a single $419 \mathrm{bp}$ intron that was removed from the remaining $1734 \mathrm{bp} ; R P B 2: 110$ of 960 bp were removed; $E F 1 \alpha$ : 132 of 1130 bp were removed. Maximum parsimony (MP) analyses were conducted in PAUP* v4.0b10 (Swofford, 2003) as heuristic searches with 100 random addition replicates and TBR branch swapping. Support for the branching topologies was evaluated by bootstrap analysis derived from 1000 replicates with 10 random addition replicates each. Maximum likelihood (ML) analyses were conducted by the quartet puzzling method in PAUP* with 10000 puzzling steps; transition/transversion ratio $=2$ (Strimmer and von Haeseler, 1996). For the multigene analyses, Lentinula lateritia, Gymnopus 

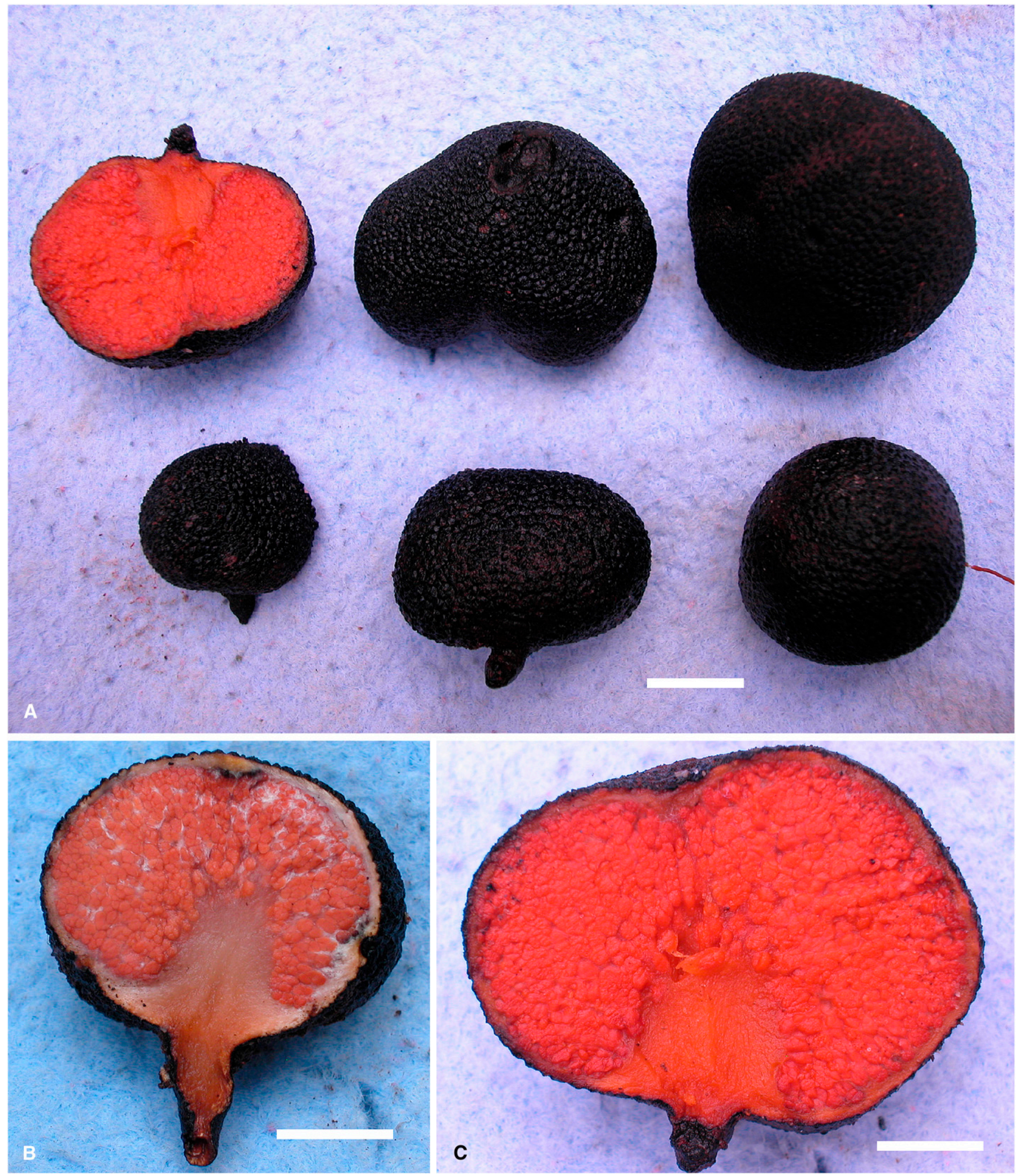

Fig. 1. Basidiomata of Guyanagaster necrorhiza. (A) Holotype; Henkel 9065. (B) Longitudinal section of basidioma showing immature gleba and well-developed peridium, columella, and stipe. (C) Mature gleba; note strong reddening of all internal tissues. Bar $=10 \mathrm{~mm}$. 

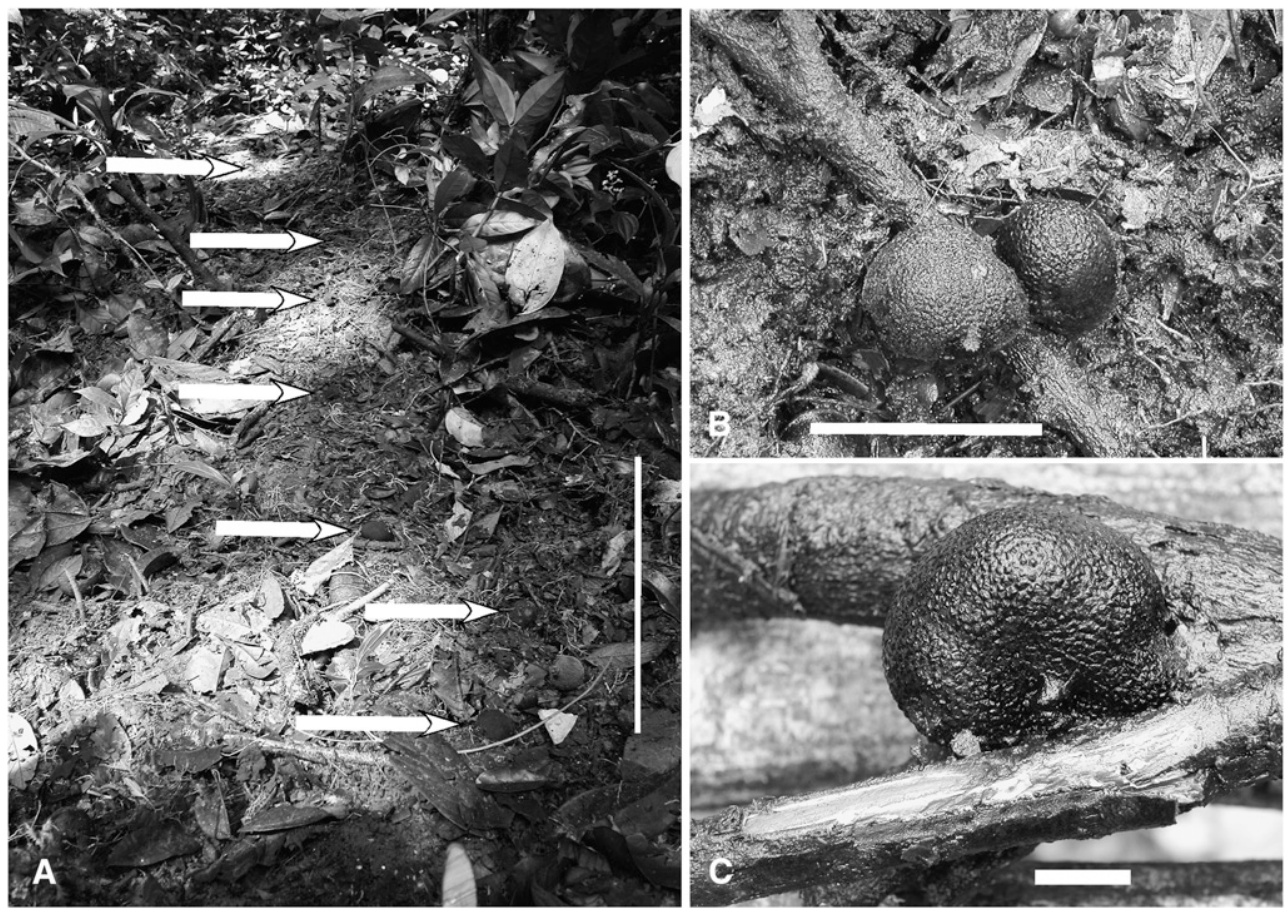

Fig. 2. Field habit of Guyanagaster necrorhiza, Upper Potaro Basin, Guyana. (A) Basidiomata fruiting above decaying root axis (note arrows). Bar $=$ $1 \mathrm{~m}$. (B) Excavated D. corymbosa root with two attached basidiomata. Bar $=10 \mathrm{~cm}$. (C) Close-up of basidioma showing attachment of stipe to root, and mycelial fans in cambial region. $\mathrm{Bar}=1 \mathrm{~cm}$.

contrarius, and Marasmius rotula as additional members of the marasmioid clade were selected as outgroup taxa (Matheny et al., 2006); for single-gene data matrices, the non-Physalacriaceae taxa were selected as outgroups for rooting purposes. Bayesian analyses were conducted on the five-gene data set in the program Mr. Bayes v. 3.12 (http://mrbayes.csit.fsu.edu/index.php; Huelsenbeck and Ronquist, 2001) with the optimum models of DNA evolution determined using the program Mr. Modeltest2 v2.2 (http://www.abc. se/ nylander/; Nylander, 2004). Posterior probability values were obtained by running one cold and three heated Markov chain Monte Carlo (MCMC) chains for 20 million generations, sampling trees every 1000 generations and discarding the initial $10 \%$ of trees as the burn in. The GTR+I+G model was selected for all three data sets, and in each case, the non-Physalacriaceae taxa were selected as outgroups for rooting purposes.

\section{TAXONOMY}

Guyanagaster T. W. Henkel, Aime and M. E. Smith gen. nov. (Figs. 1-5) - Basidiomata globosa usque ovata vel irregulariter lobata, 22-52 × 11-34 mm, nigra, verrucosa; stipes concolor, laevis, 7-10 $\times 4-6 \mathrm{~mm}$, ad radices lignosae affixus; gleba roseo-pallida usque lateritia, loculis gelatinosis; columella continua cum stipite, roseo-pallida usque rubro-aurantia; basidiosporae globosae, echinulatae, pedicellatae, avellinae, dextrinoidea, $15.5-18.5 \times 15.6-18.8 \mu \mathrm{m}$.

Etymology-Guyana; gaster $=$ stomach $($ Greek $)$, referring to the country of origin and sequestrate basidiomata.

Holotypus-Guyanagaster necrorhiza T. W. Henkel, Aime and M. E. Smith

Guyanagaster necrorhiza T. W. Henkel, Aime and M. E. Smith sp. nov. (Figs. 1-5)-Basidiomata gasteroida, globosa usque ovata vel irregulariter lobata, 22-52 × 11-35 mm, firma; peridium nigrum, verrucosum, verrucis obtusis, pyramidalibus, 0.3-0.5 mm crassis; endoperidium album, $0.8-1.5 \mathrm{~mm}$ crassum; stipes niger, laevis, 7-20 × 3-6 mm, ad radices lignosae affixus; gleba roseo-pallida usque carnea vel lateritia, loculis gelatinosis, cum albis hyphis separatis; columella continua cum stipite, roseo-pallida usque rubro-aurantia, evidenter distinctus gleba; basidiosporae globosae, echinulatae, pedicellatae, parietibus crassis, avellinae, dextrinoidea, 15.5-18.5 × 15.6-18.8 $\mu \mathrm{m}$; basidia cylindrica, 2-sterigmata, genita hyphis loculorum immaturorum; fibulae carentes.

\section{Holotypus-Henkel 9065 (BRG; isotype: HSU, FH, NY, DUKE)}

Macromorphological features of basidiomata-Basidiomata gasteroid, subepigeous to erumpent, scattered or in linear troops, attached directly to woody roots of Dicymbe trees; 22-52 $\mathrm{mm}$ broad, $11-35 \mathrm{~mm}$ tall, globose to subglobose to ovoid and irregularly broadly lobate, dense, base with smooth, sterile concolorous stipe, 7-10 × 3-6 mm, attached directly to substratum (Figs. 1, 2). Peridium black during all stages of development, moist, tough, covered in blunt, 4-5 sided polygonal nondeciduous warts, these $0.75-1.5 \mathrm{~mm}$ broad, $0.3-0.5 \mathrm{~mm}$ tall, more acuminate with age, sharply differentiated from endoperidium; endoperidium white to light pink (7A1-7A2), tough, $0.8-1.5 \mathrm{~mm}$ thick, of matted hyphae transitioning evenly to sterile, white hyphal veins between the glebal locules; gleba composed of well-defined locules and intervening veins; locules globose to ovate to subangular, $0.5-4 \mathrm{~mm}$ broad, initially pinkish white (5A2-5A3), maturing in stages to flesh pink (6A3-6A4, to 6B6) and eventually a rich brick red (8B8-8C8-8D8) evenly throughout, unchanging; hyphae separating locules initially white, light pink (7A3) in older specimens, darkening slightly 

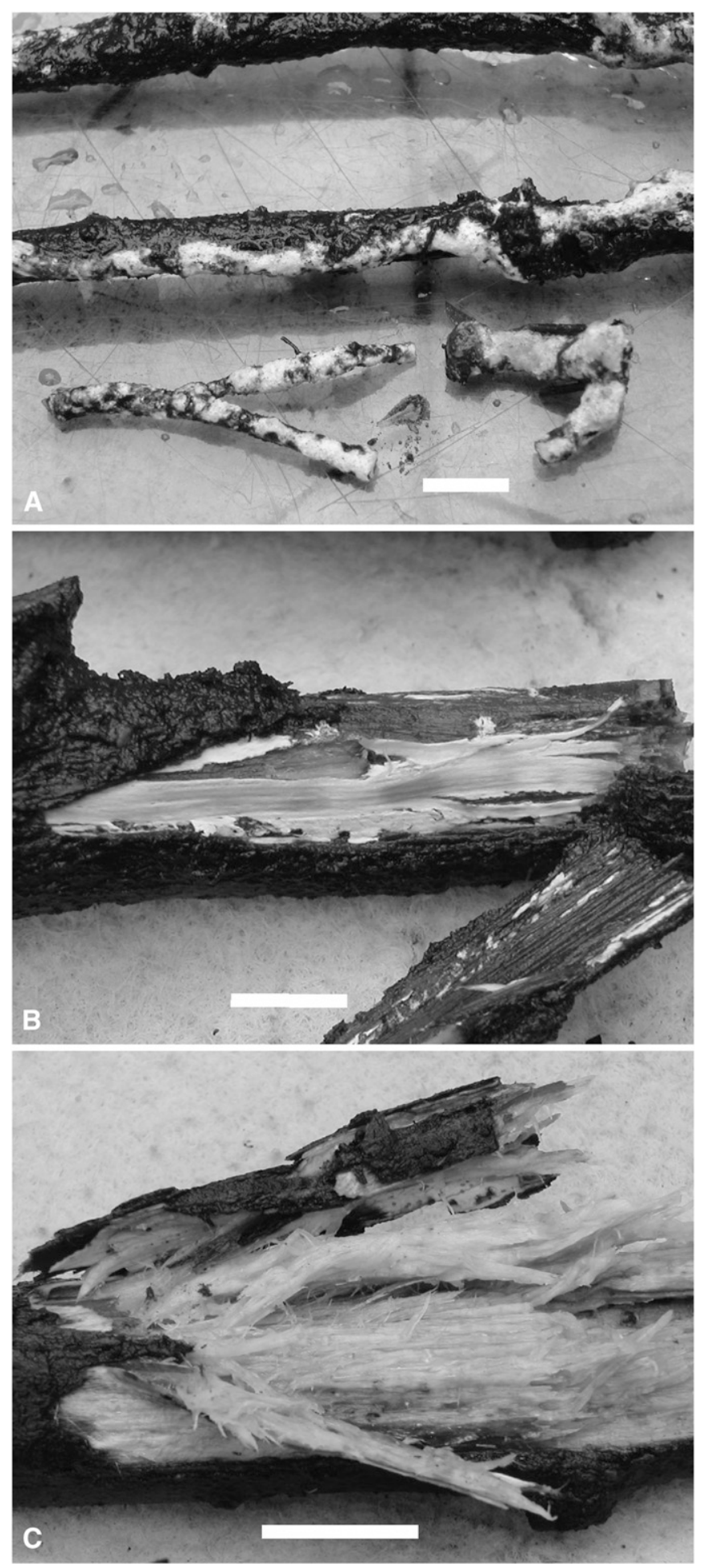

Fig. 3. Vegetative development of Guyanagaster necrorhiza on Dicymbe corymbosa. (A) Excavated roots with well-developed external hyphal cords. (B) Decaying woody roots with mycelia fans in cambium. (C) Wet, stringy, white rot. Bar $=10 \mathrm{~mm}$.

with exposure; columella well-defined, base continuous with stipe, 9-22 $\times 7-15 \mathrm{~mm}$, initially light pink ( 7A3), orange-red (7B7-8B7) with age, dense, waterlogged, of longitudinally arranged hyphae under hand lens, sharply demarcated from gleba at apex. With advanced age, entire basidioma permeated with invertebrate excavation channels; tissues between excavation channels remaining firm; without evidence of vertebrate consumption (Fig. 5). Odor mild, somewhat musty, clay-like in older specimens, taste mildly "chemical" or soapy, texture brittle when chewed. Macrochemical spot tests: $\mathrm{KOH}$ reddening endoperidium, columella, and gleba, darkening exoperidium; $\mathrm{NH}_{4} \mathrm{OH}$ reaction lacking on all surfaces.

Vegetative features - Hyphal cords proliferating along exterior of long axis of individual Dicymbe roots from $0.5-3 \mathrm{~cm}$ diameter, white, 2-4 mm diameter, roundish to subflattened, tuberculate under lens, in cross section exterior rind undifferentiated, of loosely packed, white hyphae, with gelatinous, gray core $0.5-0.75 \mathrm{~mm}$ diameter, occasionally bridging adjacent roots; forming dense yellowish mycelial fans proliferating along root cambial region, from which feeder hyphae ingress via sapwood rays; wood decay reddish when incipient, advancing to a watersaturated, stringy white rot that eventually gelatinizes (Fig. 3).

Micromorphological features of basidiomata-Exoperidium composed of agglutinated masses of anticlinal hyphae forming conical to rounded warts, in mass $168-336 \times 160-168$ $\mu \mathrm{m}$; individual hyphae of outer layer dark brown in $\mathrm{H}_{2} \mathrm{O}$, inamyloid, curved to tortuously curved, nongelatinous, 30-42 $\times$ 5-6 $\mu \mathrm{m}$, swollen at septa, apically coalescing into protruding clumps, giving warts a hairy appearance under low magnification, hyphal walls rapidly staining deep red in $\mathrm{KOH}$, with red pigment leaching into mounting medium; outer peridial hyphae subtended by a layer of subisodiametric cells, 14-22 × 12-22 $\mu \mathrm{m}$, walls in $\mathrm{H}_{2} \mathrm{O}$ yellow to light brown, $2-3 \mu \mathrm{m}$ wide, intergrading below with hyphae of endoperidium (Fig. 4A). Endoperidium 700-760 $\mu \mathrm{m}$ thick, well-differentiated from exoperidium and glebal locules, composed centrally of highly interwoven, branching, anastomosing hyphae that are irregularly inflated, 2-5 $\mu \mathrm{m}$ wide, hyaline in water and $\mathrm{KOH}$, inamyloid, thinwalled, moderately gelatinizing to yield an irregularly "honeycombed" appearance in mass; near extreme distal transition with exoperidium cells becoming more inflated and subanticlinal, toward the locules hyphae becoming thinner, more tightly interwoven. Sterile hyphae separating locules similar to endoperidial hyphae, parallel-interwoven, weakly gelatinous. Glebal locules in thin section globose to subglobose, 163-1020 $\times$ 255-1500 $\mu \mathrm{m}$, tissues densely gelatinous such that locules are difficult to flatten on a microscope slide, preventing permeation of stains; locule tissue primarily of tightly packed basidiospores encased in a gel matrix, at maturity mostly lacking intact hyphae, when present hyphae 1-2 $\mu$ m wide; well-organized hymenium lacking (Fig. 4B). Basidia apparently 2-sterigmate, difficult to observe even in microtome sections, more or less cylindrical and undifferentiated from subtending hyphae, occasionally inflated near apex and tapering evenly toward base, basal septum usually inevident, hyaline in water, thin-walled, originating as side branches from locular hyphae in immature locules; sterigmata difficult to observe, apparently long, arising at angles from sides of basidium apex. Basidiospores globose; in $\mathrm{H}_{2} \mathrm{O}$ and $\mathrm{KOH}$ light tannish brown with faint pinkish overtones, in Melzer's rich burgundy brown and therefore darkly dextrinoid, main body thick-walled, outer spore wall 1-2.4 $\mu \mathrm{m}$ wide, inner wall $0.75-1 \mu \mathrm{m}$ wide, with regularly globose lumen, covered in entirety with straight to slightly recurved, narrow, cylindrical, apically acuminate spines, which are tightly packed and equidistant throughout, 1.7-2.2 $\mu \mathrm{m}$ tall, apical recurvations sometimes 

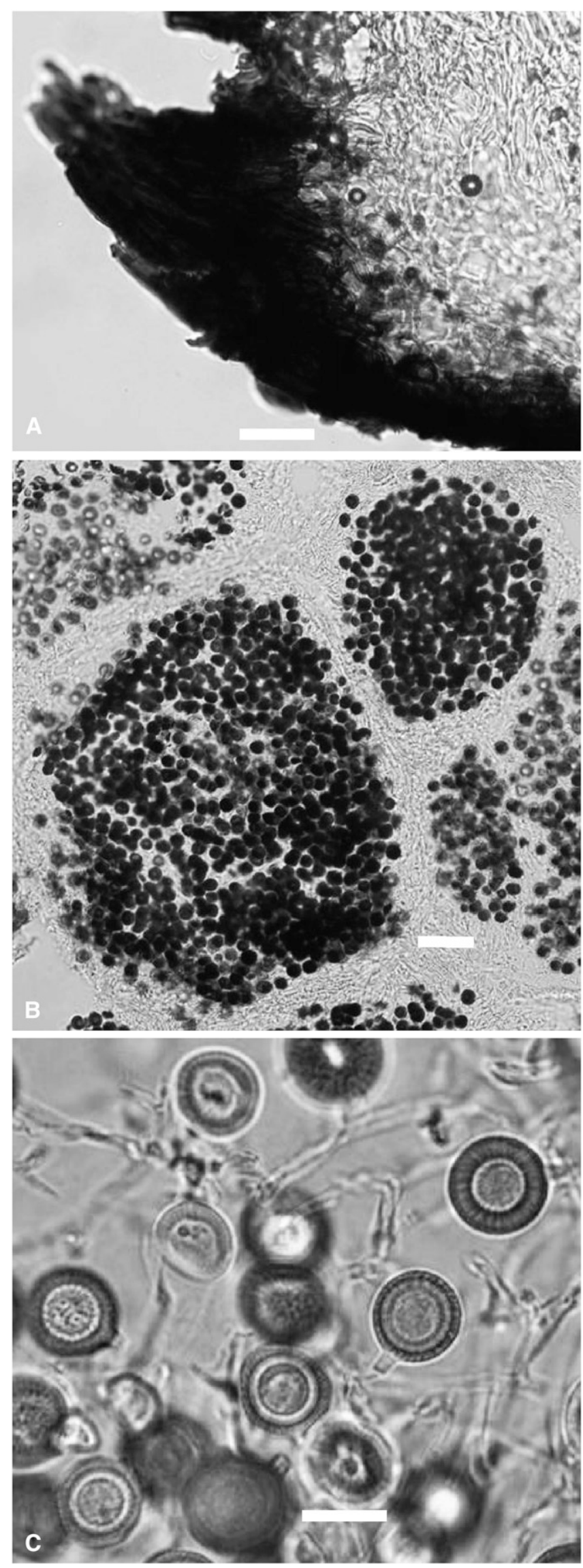

unidirectional and giving the spore ornaments a "combed" appearance, spines apparently immersed in a gelatinous matrix; without spines $(10.8-) 12.1-15.8 \times 12-15.5(-16.1) \mu \mathrm{m}$ (mean = $\left.13.5 \pm 0.3 \times 13.5 \pm 0.3 \mathrm{um}, Q_{\mathrm{r}}=0.93-1.06, Q_{\mathrm{m}}=1.0 \pm 0.01\right)$; with spines included $15.5-18.5 \times 15.6-18.8(-19.4) \mu \mathrm{m}$ (mean $=$ $\left.17.0 \pm 0.2 \times 16.8 \pm 0.3 \mu \mathrm{m}, Q_{\mathrm{r}}=0.95-1.05, Q_{\mathrm{m}}=1.0 \pm 0.01\right)$, ( $N=20$ basidiospores); in side view with robust, symmetrically positioned pedicel, $2.9-4.7 \times 2.1-2.5 \mu \mathrm{m}$; immature basidiospores hyaline to light pink, wall thinner and spines longer relative to overall diameter, this situation reversing with maturity apparently due to progressive outward thickening of wall and resulting increase in basidiospore diameter, without attendant increase in spine length (Fig. 4C). Columella tissue composed of moderately interwoven, tightly packed, nongelatinous hyphae; hyphae thin-walled, hyaline in water and $\mathrm{KOH}$, of variable widths, (2.5-)5-10(-18) $\mu \mathrm{m}$. Clamp connections absent in all tissues.

Habit, habitat, and distribution-Rare, scattered to abundant between leaf litter and mineral soil attached to decaying woody roots of Dicymbe corymbosa and D. altsonii in tropical rainforest, known only from the Upper Potaro Basin of Guyana.

Etymology-Nekros = death, corpse; rhiza = root (Greek), referring to the root wood decaying, putatively parasitic habit of the fungus.

Specimens examined-Guyana. Region 8 Potaro-SiparuniPakaraima Mountains, Upper Potaro River Basin, elevation 710-750 m; vicinity of base camp, 29 June 2001, Henkel 8418 (BRG; HSU); vicinity of base camp, 11 June 2002, Aime 1956 (BRG, LSUM); vicinity of base camp, 4 July 2003, Aime 2312 (BRG, LSUM); $2.5 \mathrm{~km}$ southeast of base camp, Dicymbe plot 1 , 27 July 2008, Henkel 8989 (BRG; HSU, FH); 2 km southwest of base camp, on roots of fallen Dicymbe corymbosa tree, 22 July 2009, Henkel 9065 (Holotype: BRG; isotype: HSU, FH, NY, DUKE), Henkel 9065R hyphal cord (HSU), Henkel 9065MF mycelial fan (HSU); $8 \mathrm{~km}$ southeast of base camp at Tadang Creek, on roots of standing dead Dicymbe altsonii tree, 24 December 2009, Henkel 9135 (BRG; HSU); 2 km southwest of base camp, on roots of fallen Dicymbe corymbosa tree, 17 May 2010, Aime 3950 (BRG; LSUM).

MycoBank numbers-MB 515527 (genus); MB 515528 (species).

Commentary-Guyanagaster necrorhiza is easily recognized in the field by its black, verrucose, subglobose to broadly lobate, firm basidiomata, which emerge slightly from the leaf litter in the vicinity of standing dead trees or recent treefalls. A longitudinal section reveals a firm, pinkish-flesh to brick red, loculate gleba, and distinct columella. Excavations of basidiomata reveal a black, smooth stipe directly attached to decaying woody roots, with associated white, exterior hyphal cords, mycelia fans in the root cambium, and wet, stringy,

Fig. 4. Microscopic features of Guyanagaster necrorhiza (holotype; Henkel 9065); bright field optics; all mounts in $3 \% \mathrm{KOH}$. (A) Interface between the exoperidium and endoperidium, longitudinal section (LS). Bar $=40 \mu \mathrm{m}$. (B) Glebal locules separated by sterile tissues, LS. Bar = $40 \mu \mathrm{m}$. (C) Basidiospores and locular hyphae. Bar $=10 \mathrm{um}$. 


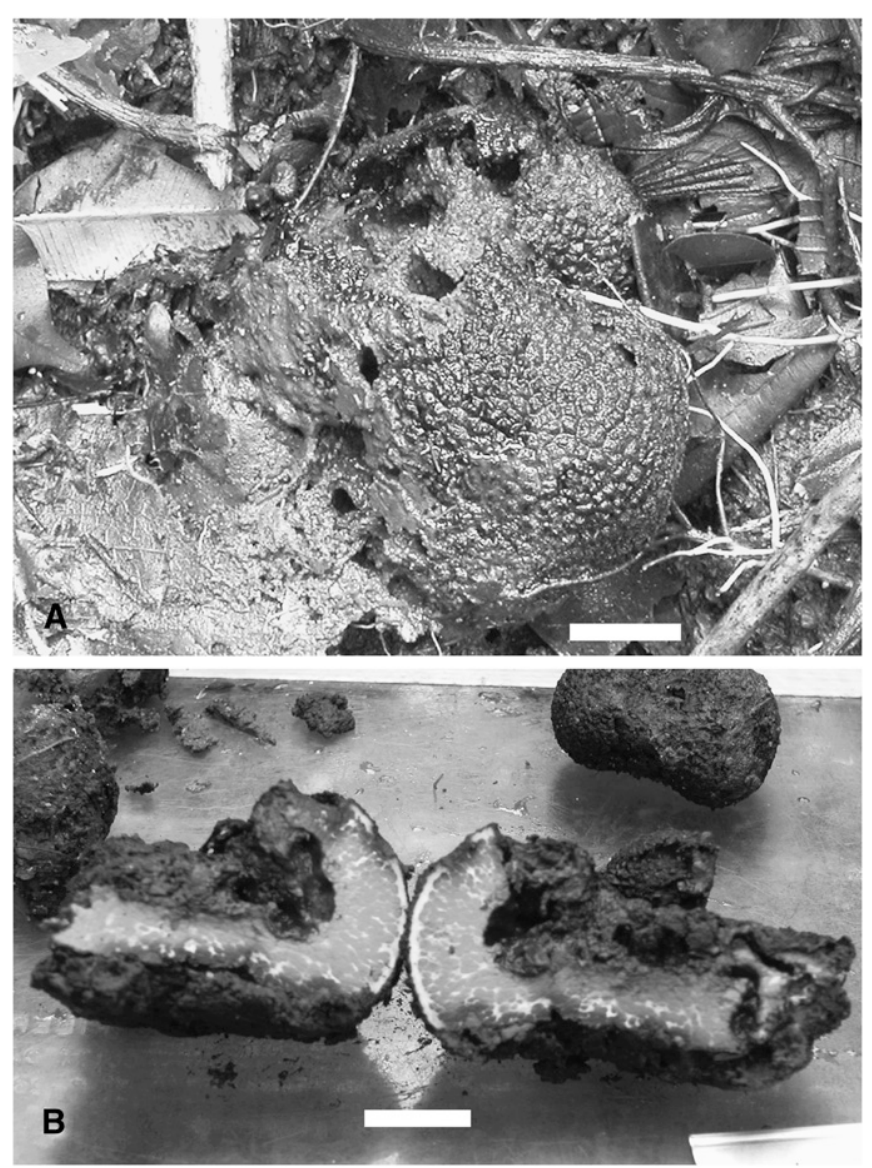

Fig. 5. Senescent basidiomata of Guyanagaster necrorhiza. (A) Mature basidioma in the field showing arthropod excavation channels through the peridium, with associated frass (Henkel 9135; on Dicymbe altsonii). (B) Section showing extensive excavation channels through otherwise intact gleba (Henkel 9065; on Dicymbe corymbosa). Bar = $10 \mathrm{~mm}$.

white rot of root wood. With advanced age, basidiomata maintain their firmness and moisture content, but are heavily excavated by arthropods.

Phylogenetic analyses fully support the placement of Guyanagaster within the Physalacriaceae in the Agaricales and that the closest related genus within the family is the lamellate Armillaria (Fig. 6). However, the exact relationship between Armillaria and Guyanagaster could not be definitively resolved. The five-gene ML analysis (Fig. 6) and the EFl $\alpha$ ML and MP analyses (Appendix S1, see Supplemental Data with the online version of this article) suggest that Guyanagaster represents a sister taxon to Armillaria, whereas the five-gene Bayesian and parsimony analyses (not shown) as well the 28S rDNA ML and PP analyses (online Appendix S2) suggest that Guyanagaster may be derived from within Armillaria, rendering Armillaria paraphyletic. With due consideration to these molecular results, we have chosen to erect Guyanagaster as a new genus for the following reasons: (1) the highly divergent basidioma morphology of Guyanagaster relative to all known species of Armillaria worldwide, including the sequestrate subhypogeous fruiting habit, strongly reduced stipe, gelatinized locules, bright-red glebal and black peridial colors, spinose basidiospores, inconspicuous basidia, and disorganized fertile tissues; (2) the radi- cally different basidiospore dispersal in Guyanagaster relative to Armillaria; and (3) the differences in vegetative organs (e.g., the invasive hyphal cords of Guyanagaster are loosely organized, nonsclerotized, and white, whereas the rhizomorphs of all known Armillaria spp. are highly organized with a dense, melanized rind; Pegler, 2000). For basidiomata, hyphal cords, and mycelial fans, the ITS rDNA sequences were identical, confirming the root decay habit of Guyanagaster.

\section{DISCUSSION}

Guyanagaster is unique among sequestrate genera throughout the Agaricomycetes due to its combination of a black, verrucose peridium that leaches reddish pigments in $\mathrm{KOH}$, short stipe and radiating columella, pink to brick-red gel-filled glebal locules, inconspicuous basidia, pinkish, spinose, strongly dextrinoid basidiospores with prominent pedicels, habit of fruiting directly from woody roots, and its phylogenetic affinities with Armillaria.

Morphologically similar sequestrate fungi-Among sequestrate genera of the Agaricales, Guyanagaster is similar to Cribbea A. H. Sm. and D. A. Reid (Physalacriaceae) in its basidiospore characteristics and wood decay habit. However, Cribbea species have basidia arranged in an obvious hymenium with robust cystidia and a hymeniform pileipellis (Lebel and Cratcheside, 2009). Our phylogenetic analyses of 28S sequence data show Cribbea as derived from within the Xerula/Oudemansiella lineage, and thus only distantly related to Guyanagaster (online Appendix S2; Lebel and Cratcheside, 2009). Species of Hydnangium Wallr. (Hydnangiaceae) have pedicillate basidiospores with similar spore ornaments to those of Guyanagaster, but differ in having hyaline basidiospores, robust basidia, and smooth, usually pink or orange peridia; additionally, Hydnangium sensu stricto has originated within the lamellate genus Laccaria (Pegler and Young, 1979; Kropp and Mueller, 1999), which is now known to belong to the agaricoid lineage of Agaricales, rather than the marasmioid lineage to which Physalacriaceae belongs (Matheny et al., 2006). Species of Stephanospora (Berk.) Pat. (Stephanosporaceae) have spinulose basidiospores and putatively saprotrophic habits, but differ from Guyanagaster in their orange or yellow basidiomata that lack a stipe or columella and have nondextrinoid basidiospores with peri-appendicular coronas. In addition, Stephanospora is phylogenetically distant to Guyanagaster (Martin et al., 2004; Tedersoo et al., 2010).

Among sequestrate genera of the Boletales, Guyanagaster could potentially be confused with Durianella Desjardin, A. W. Wilson and Binder. The monotypic Durianella echinulata (Corner and Hawker) Desjardin, A. W. Wilson and Binder from tropical Asia has a verrucose peridium, gel-filled locules, spinose basidiospores, and a subhypogeous fruiting habit (Desjardin et al., 2008). However, D. echinulata has tissues that oxidize blue, a golden-yellow peridium that does not leach red pigment in $\mathrm{KOH}$, inamyloid basidiospores lacking a pronounced pedicel, an ectomycorrhizal habit, and is a well-supported member of the Boletineae clade (Desjardin et al., 2008). Some species of the polyphyletic Octaviania Vittad. (Boletales) superfically resemble Guyanagaster in peridial and glebal structure and basidiospore ornamentation but lack a glebal columella and exhibit an oxidation reaction when cut or bruised (Montecchi and Sarasini, 2001; Trappe et al., 2009; Orihara et al., 2010). 


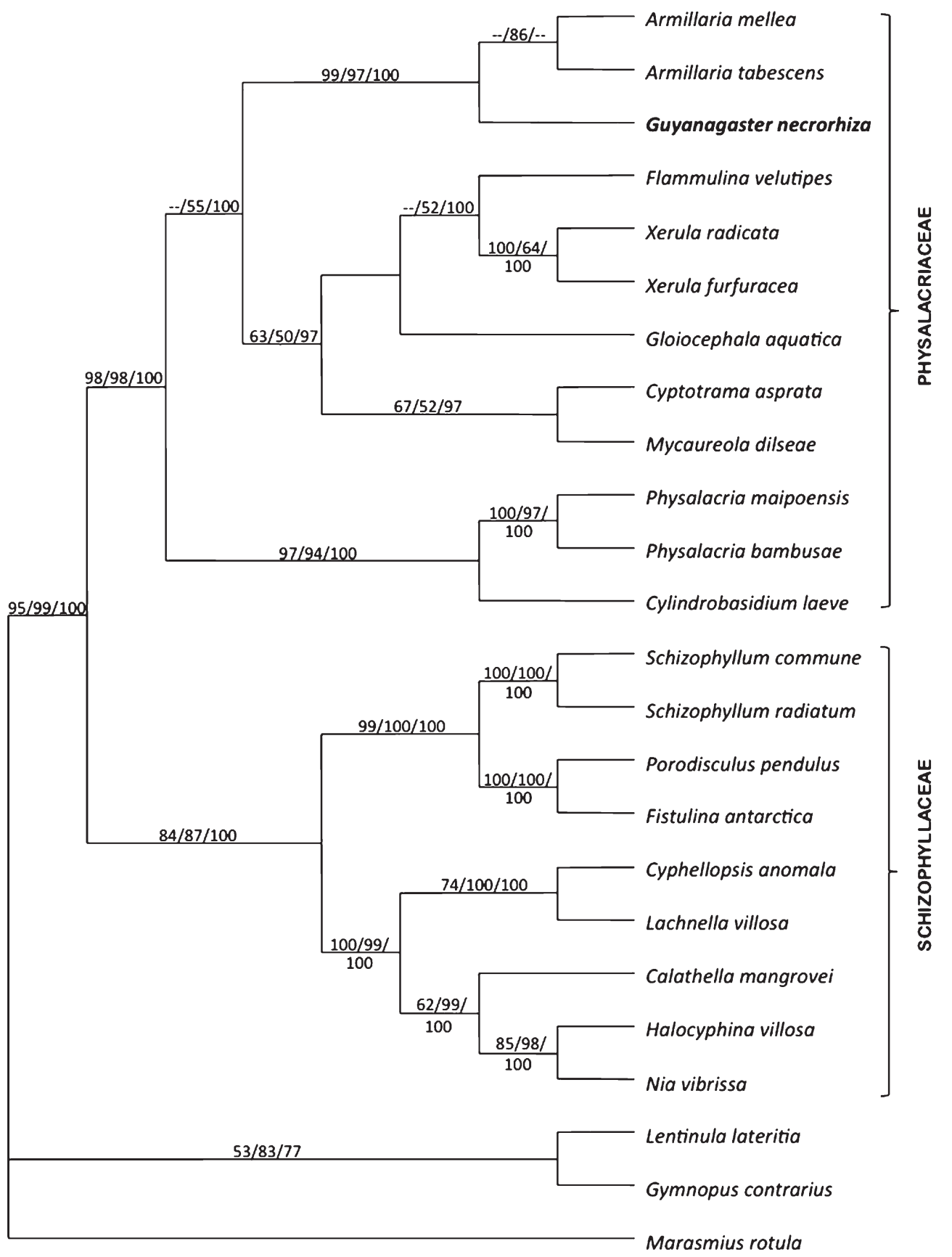

Fig. 6. Phylogram generated from maximum likelihood analysis of five gene regions (18S, ITS, and 28S rDNA, RBP2, and EF1 $\alpha$ ) from 24 taxa of Agaricales, showing a sister relationship of Guyanagaster necrorhiza with the genus Armillaria in the Physalacriaceae. Lentinula lateritia, Gymnopus contrarius, and Marasmius rotula were used as outgroup taxa. The phylogram was obtained from 10000 quartet puzzling steps, with a transition/transversion ratio $=2$. Support values shown above branches represent MP bootstrapping/ML quartet puzzling/Bayesian posterior probabilities. See Methods for analytical details.

Some Sclerogaster species (Geastrales) share features with Guyanagaster, including a pinkish or orangish gleba and ornamented basidiospores (Hosaka and Castellano, 2008). However, most Sclerogaster species have smooth, light-colored peridia, astipitate, acolumellate basidiomata, and basidiospores that are $<10 \mu \mathrm{m}$ diameter. The neotropical Sclerogaster luteocarneus (Bres.) Zeller and C. W. Dodge is similar to Guyanagaster in having spinose, pedicellate basidiospores and a short columella, but differs in its smooth, yellowish to brown perid- ium, yellowish gleba, and distinct, clavate basidia (Zeller and Dodge, 1935).

Phylogenetic and life history considerations-Molecular data show unequivocally that Guyanagaster has strong affinities with the lamellate Armillaria, a mushroom genus which otherwise is not closely related to any known sequestrate fungi (Pegler, 2000; Matheny et al., 2006). In addition, fruiting habit, sequence congruence between basidiomata, hyphal cords, and 
mycelia fans, and the associated stringy, white rot suggest a similar wood decay habit, and possibly root parasitism, between Guyanagaster and Armillaria (Termorshuizen, 2000). While Guyanagaster may be able to colonize live roots of host trees by belowground proliferation of hyphal cords in a manner similar to many Armillaria species, more information is needed to ascertain its parasitic capacity. From the standpoint of basidioma morphology, there is little congruence macro- or microscopically between the sequestrate Guyanagaster and lamellate, agaricoid Armillaria, although some degree of basidiospore ornamentation has been noted in Armillaria spp. (Bennell et al., 1985). At the least, Guyanagaster is an entirely novel sequestrate taxon close to Armillaria within the largely nonsequestrate Physalacriaceae and as such represents a highly significant discovery.

Although the exact basidiospore dispersal mechanism of $G$. necrorhiza is currently unknown, field observations suggest that arthropods may be involved. First, many mature basidiomata were extensively excavated by an unidentified assemblage of arthropods, noted when multiaged troops of $G$. necrorhiza basidiomata were examined at specific collecting sites on different host tree species (TH 9065 and TH 9135; Fig. 5). Second, G. necrorhiza basidiomata appeared resistant to decay over a period of weeks and basidiospores remained immersed in a firm, gelatinized gleba except in portions where arthropods were excavating. Third, basidiomata of G. necrorhiza lack a powdery spore mass or strong odors, suggesting that neither wind or vertebrate mycophagy are likely dispersal vectors. Given the root decomposing, and possibly parasitic, habit of $G$. necrorhiza it is conceivable that basidiospores are successfully vectored into the belowground environment by arthropods. Lilleskov and Bruns (2005) demonstrated that arthropods, including flies and beetles, were effective dispersers of basidiospores of the nonsequestrate, subterranean-fruiting ectomycorrhizal fungus Tomentella sublilacina. If similar mechanisms occur with $G$. necrorhiza, this would be the first recorded case combining such specialized dispersal and nutritional strategies in a fully sequestrate fungal species (J. M. Trappe, Oregon State University, personal communication).

\section{LITERATURE CITED}

AIME, M. C., AND T. W. HENKEL. 2008. Where are the missing fungi? Western Guyana as a potential hotspot for fungal diversity. Association for Tropical Biology Annual Meeting, Paramaribo, Surinam (abstract).

Aime, M. C., AND W. Phillips-Mora. 2005. The causal agents of witches' broom and frosty pod rot of cacao (chocolate, Theobroma cacao) form a new lineage of Marasmiaceae. Mycologia 97: 1012-1022.

Albee-Scott, S. R. 2007. Does secotioid inertia drive the evolution of false-truffles? Mycological Research 111: 1030-1039.

Bennell, A. P., R. Watling, And G. Kile. 1985. Spore ornamentation in Armillaria (Agaricales). Transactions of the British Mycological Society 84: 447-455.

Binder, M., AND D. S. HibBetT. 2006. Molecular systematics and biological diversification of Boletales. Mycologia 98: 971-981.

Binder, M., D. S. Hibbett, Z. Wang, and W. F. Farnham. 2006. Evolutionary relationships of Mycaureola dilseae (Agaricales), a basidiomycete pathogen of a subtidal rhodophyte. American Journal of Botany 93: 547-556.

Bruns, T. D., R. Fogel, T. J. White, And J. Palmer. 1989. Accelerated evolution of a false truffle from a mushroom ancestor. Nature 339: $140-142$.

CoKer, W. C., AND J. N. Couch. 1928. The gasteromycetes of the eastern United States and Canada. University of North Carolina Press, Chapel Hill, North Carolina, USA.
Desjardin, D. E., A. W. Wilson, AND M. Binder. 2008. Durianella, a new gasteroid genus of boletes from Malaysia. Mycologia 100: 956-961.

GARDES, M., AND T. D. BRUns. 1993. ITS primers with enhanced specificity for basidiomycetes-Application to the identification of mycorrhizae and rusts. Molecular Ecology 2: 113-118.

Grubisha, L. C., J. M. Trappe, R. Molina, and J. W. Spatafora. 2002. Biology of the ectomycorrhizal genus Rhizopogon. VI. Reexamination of infrageneric relationships inferred from phylogenetic analyses of ITS sequences. Mycologia 94: 607-619.

HeIM, R. 1971. The interrelationships between the Agaricales and Gasteromycetes. In R. H. Petersen [ed.], Evolution in the higher Basidiomycetes, 505-534. University of Tennessee Press, Knoxville, Tennessee, USA.

Henkel, T. W. 2003. Monodominance in the ectomycorrhizal Dicymbe corymbosa (Caesalpiniaceae) from Guyana. Journal of Tropical Ecology 19: 417-437.

Hibbett, D. S., E. M. Pine, E. Langer, G. Langer, and M. J. Donoghue. 1997. Evolution of gilled mushrooms and puffballs inferred from ribosomal DNA sequences. Proceedings of the National Academy of Sciences, USA 94: 12002-12006.

Holmgren, P. K., N. H. Holmgren, And L. C. Barnett. 1990. Index herbariorum, part I: The herbaria of the world. Regnum Vegetabile 120: $1-693$.

Hosaka, K., S. T. Bates, R. E. Beever, M. A. Castellano, W. Colgan III, L. S. Dominguez, E. R. Nouhra, ET AL. 2006. Molecular phylogenetics of the gomphoid-phalloid fungi with an establishment of the new subclass Phallomycetidae and two new orders. Mycologia 98: 949-959.

Hosaka, K., and M. A. Castellano. 2008. Molecular phylogenetics of Geastrales with special emphasis on the position of Sclerogaster. Bulletin of the National Museum of Nature and Science, B. Biological Sciences 34: 161-173.

HUELSENBECK, J. P., AND F. RonQuist. 2001. MRBAYES: Bayesian inference of phylogenetic trees. Bioinformatics (Oxford, England) 17: 754-755.

INGOLD, C. T. 1965. Spore liberation. Clarendon, Oxford, UK.

Kendrick, B. 1992. The fifth kingdom. Focus, Newburyport, Massachusetts, USA.

Kornerup, A., AND J. H. WANSCHER. 1978. Methuen handbook of colour. 3rd ed. Eyre Methuen, London, UK.

Kretzer, A., And T. D. Bruns. 1997. Molecular revisitation of the genus Gastrosuillus. Mycologia 89: 586-589.

Kropp, B. R., AND G. M. Mueller. 1999. Laccaria. In J. W. G. Cairney, S. M. Chambers [eds.], Ectomycorrhizal fungi: Key genera in profile, 65-88. Springer, Berlin, Germany.

Largent, D. L., D. Johnson, and R. Watling. 1977. How to identify mushrooms to genus III. Microscopic features. Mad River Press, Eureka, California, USA.

Lebel, T., and P. S. Cratcheside. 2009. The truffle genus Cribbea (Physalacriaceae, Agaricales) in Australia. Australian Systematic Botany 22: 39-45.

Lilleskov, E. A., AND T. D. Bruns. 2005. Spore dispersal of a resupinate ectomycorrhizal fungus, Tomentella sublilacina, via soil food webs. Mycologia 97: 762-769.

Martin, M. P., N. Hogberg, ANd J. Listosella. 1999. Macowanites messapicoides, a hypogeous relative of Russula messapica. Mycological Research 103: 203-208.

Martin, M. P., S. Raidl, ANd N. T. Telleria. 2004. Molecular analyses confirm the relationship between Stephanospora caroticolor and Lindtneria trachyspora. Mycotaxon 90: 133-140.

Matheny, P. B. 2005. Improving phylogenetic inference of mushrooms with RPB1 and RPB2 nucleotide sequences (Inocybe, Agaricales). Molecular Phylogenetics and Evolution 35: 1-20.

Matheny, P. B., J. M. Curtis, V. Hofstetter, M. C. Aime, J. M. Moncalvo, Z. W. Ge, Z. L. YAnG, et AL. 2006. Major clades of Agaricales: A multilocus phylogenetic overview. Mycologia 98: 982-995.

Miller, O. K. JR., AND M. C. Aime. 2001. Systematics, ecology, and world distribution in the genus Chroogomphus (Gomphidiaceae). 
In J. K. Misra, B. W. Horn, [eds.], Trichomycetes and other fungal groups: Robert W. Lichtwardt commemoration volume, 315-333. Science Publishers, Enfield, New Hampshire, USA.

Miller, O. K. JR., T. W. Henkel, T. Y. James, and S. L. Miller. 2001. Pseudotulostoma, a remarkable new volvate genus in the Elaphomycetaceae from Guyana. Mycological Research 105: $1268-1272$.

Miller, O. K. JR., AND H. H. Miller. 1988. GasteromycetesMorphological and developmental features with keys to the orders, families, and genera. Mad River Press, Eureka, California, USA.

Miller, S. L., M. C. Aime, And T. W. Henkel. 2002. The Russulaceae of the Pakaraima Mountains of Guyana I. New species of pleurotoid Lactarius. Mycologia 94: 545-553.

Miller, S. L., T. M. McClean, J.F. Walker, and B. Buyck. 2001. A molecular phylogeny of the Russulaceae including agaricoid, gasteroid, and pleurotoid taxa. Mycologia 93: 344-354.

Montecchi, A., And M. Sarasini. 2001. Funghi Ipogei D’Europa. Associazione Micologica Bresadola, Trento, Italy.

Mueller, G. M., AND E. M. Pine. 1994. DNA data provide evidence on the evolutionary relationships between mushrooms and false truffles. McIlvainea 11: 61-74.

Mueller, G.M.,J.P.SChmit,P.R.LeAcock, B. Buyck, J.Cifuentes, D.E. Desjardin, R. E. Halling, ET AL. 2007. Global diversity and distribution of macrofungi. Biodiversity and Conservation 16: 37-48.

Nylander, J. A. A. 2004. MrModeltest v2. Program distributed by the author. Evolutionary Biology Centre, Uppsala University, Uppsala, Sweden.

Orihara, T., F. Sawada, S. Ikeda, M. Yamato, C. Tanaka, N Shimomura, M. Hashiya, and K. Iwase. 2010. Taxonomic reconsideration of a sequestrate fungus, Octaviania columellifera, with the proposal of a new genus, Heliogaster, and its phylogenetic relationships in the Boletales. Mycologia 102: 108-121.

Pegler, D. N. 2000. Taxonomy, nomenclature and description of Armillaria. In R. T. V. Fox [ed.], Armillaria root rot: Biology and control of honey fungus, 81-93. Intercept, Andover, UK.

Pegler, D. N., And T. W. H. Young. 1979. The gasteroid Russulales. Transactions of the British Mycological Society 72: 353-388.

Peintner, U., N. L. Bougher, M. A. Castellano, J. M. Moncalvo, M. M. Moser, J. M. Trappe, and R. Vilgalys. 2001. Multiple origins of sequestrate fungi related to Cortinarius (Cortinariaceae). American Journal of Botany 88: 2168-2179.

Rehner, S. A., AND E. BucKley. 2005. A Beauveria phylogeny inferred from nuclear ITS and EF1- $\alpha$ sequences: Evidence for cryptic diversification and links to Cordyceps teleomorphs. Mycologia 97: 84-98.

REIJNDERS, A. F. M. 1963. Les problemes du developement des carpophores des Agaricales et de quelques groups voisins. W. Junk, The Hague, Netherlands.

REIJNDERS, A. F. M. 2000. A morphogenetic analysis of the basic characters of the gasteromycetes and their relation to other basidiomycetes. Mycological Research 104: 900-910.
SINGER, R. 1971. A revision of the genus Melanomphalia as a basis for the phylogeny of the Crepidotaceae. In R. H. Petersen [ed.], Evolution in the higher Basidiomycetes, 441-480. University of Tennessee Press, Knoxville, Tennessee, USA.

Singer, R. 1986. The Agaricales in modern taxonomy, 4th ed. Koeltz Scientific Books, Koenigstein, Germany.

Smith, M. E., G. W. Douhan, AND D. M. Rizzo. 2007. Ectomycorrhizal community structure in a xeric Quercus woodland as inferred from rDNA sequence analysis of bulked ectomycorrhizal roots and sporocarps. New Phytologist 174: 847-863.

Smith, M. E., J. M. Trappe, D. M. Rizzo, and S. L. Miller. 2006. Gymnomyces xerophilus sp. nov. (sequestrate Russulaceae), an ectomycorrhizal associate of Quercus in California. Mycological Research 110: 575-582.

Strimmer, K., AND A. von Haeseler. 1996. Quartet puzzling: A quartet maximum likelihood method for reconstructing tree topologies. Molecular Biology and Evolution 13: 964-969.

SwOFFord, D. L. 2003. PAUP*: Phylogenetic analysis using parsimony (*and other methods), version 4. Sinauer, Sunderland, Massachusetts, USA.

Tedersoo, L., T. W. May, and M. E. Smith. 2010. Ectomycorrhizal lifestyle in fungi: Global diversity, distribution and evolution of phylogenetic lineages. Mycorrhiza 20: 217-263.

Tedersoo, L., J. Teele, B. M. Horton, K. Abarenkov, T. Suvi, I. SAAR, AND U. KõlJalg. 2008. Strong host preference of ectomycorrhizal fungi in a Tasmanian wet sclerophyll forest as revealed by DNA barcoding and taxon-specific primers. New Phytologist 180: 479-490.

Termorshuizen, A. J. 2000. Ecology and epidemiology of Armillaria. In R. T. V. Fox [ed.], Armillaria root rot: Biology and control of honey fungus, 45-63. Intercept, Andover, UK.

Thiers, H. D. 1984. The secotioid syndrome. Mycologia 76: 1-8.

Trappe, J. M., and A. W. Claridge. 2005. Hypogeous fungi: Evolution of reproductive and dispersal strategies through interactions with animals and mycorrhizal plants. In J. Dighton, J. M. White, and P. Oudemans [eds.], The fungal community: Its organization and role in the ecosystem, 3rd ed., 613-623. Taylor and Francis, Boca Raton, Louisiana, USA.

Trappe, J. M., R. Molina, D. L. Luoma, E. Cázares, D. Pilz, J. E. Smith, M. A. Castellano, et Al. 2009. Diversity, ecology and conservation of truffle fungi in forests of the Pacific Northwest. USDA Forest Service General Technical Report PNW-GTR- 772, Pacific Northwest Research Station, Portland, Oregon, USA.

White, T. J., T. D. Bruns, S. LeE, AND J. TAYlor. 1990. Amplification and direct sequencing of fungal ribosomal RNA genes for phylogenies. In M. A. Innis, D. H. Gelfand, J. J. Sninsky, and T. J. White [eds.], PCR protocols: A guide to methods and applications, 315-322. Academic Press, San Diego, California, USA.

Zeller, S. M., AND C. W. Dodge. 1935. New species of Hydnangiaceae. Annals of the Missouri Botanical Garden 22: 365-373. 


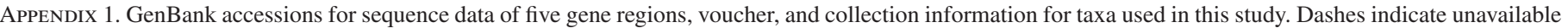
data for that gene region.

Taxon; GenBank accession: 28S, 18S, ITS, RPB2, EF1 $\alpha$; Voucher specimen, Collection locale; Herbarium.

Armillaria affinis (Singer) T.J. Volk \& Burds.; AF261356, - - , - Armillaria fumosa Kile \& Watling; DQ338552, —, —, —, - Armillaria gemina Bérubé \& Dessur.; —, - - - , FJ618670. Armillaria heimii Pegler; FJ618737, —, —, —, FJ618651. Armillaria hinnulea Kile \& Watling; DQ338555, —, 一, —, FJ618663. Armillaria limonea (G. Stev.) Boesew.; FJ618740, —, —, —, FJ618654. Armillaria mellea (Vahl) P. Kumm.; AY700194, AY787217, AY789081, AY780938, AY881023. Armillaria montagnei (Singer) Herink; FJ711623, _, - , - - Armillaria nabsnona T.J. Volk \& Burds.; DQ338542, - , - , 一, Armillaria novae-zealandiae (G. Stev.) Herink; FJ618736, - , - , FJ618650. Armillaria ostoyae (Romagn.) Herink; FJ618765, - , —, - . Armillaria pallidula Kile \& Watling; FJ618752, _, _, - , Armillaria puiggarii Speg.; FJ618722, —, - , 一, FJ618636. Armillaria sinapina Bérubé \& Dessur.; FJ618741, —, —, —, FJ618676. Armillaria sp.; FJ711619, - , - - - - Armillaria sparrei (Singer) Herink; FJ618750, —, 一, - - - Armillaria tabescens (Scop.) Emel; AF042593, DQ851572, AY213590, —, FJ618674. Calathella mangrovei E.B.G. Jones \& Agerer; AF426954, AF426948, AY571029, —, —. Cheimonophyllum candidissimum (Berk. \& M.A. Curtis) Singer; DQ457654, - , - , —. Cribbea gloriosa (D.A. Reid) A.H. Sm. \& D.A. Reid; FJ178111, -,,-- Cribbea turbinispora Catcheside \& T. Lebel; FJ178113, —, —, - - - Crinipellis sp.; AY916699, _, - _, - Cylindrobasidium laeve (Pers.) Chamuris; DQ234541, AF518576, DQ205682, AY536283, -. Cylindrobasidium torrendii (Bres.) Hjortstam; DQ234541, - , - , —. Cyphella digitalis (Alb. \& Schwein.) Fr.; AY635771, _, —, —, Cyphellopsis anomala (Pers.) Donk; AF426955, AF426949, AY571034, -, - Cyptotrama asprata (Berk.) Redhead \& Ginns; AF261353, DQ440637, DQ097355, —, - Fistulina antarctica Speg.; AY293181, AY293131, DQ486702, DQ472713, _. Fistulina hepatica (Schaeff.) With.; AY571004, —, - - - - Flammulina velutipes (Curtis) Singer; AY639883, AY665781, AY854073, AY786055, AY883423. Gloiocephala aquatica Desjardin, Mart.-Peck \& Rajchenb.; DQ097343, AY705968, DQ097356, DQ472715, _. Gloiocephala phormiorum E. Horak \& Desjardin; DQ097346, —, - - —, - Guyanagaster necrorhiza T.W. Henkel, Aime \& M.E. Smith; HM136873, _, _, _, _; MCA 1956; Guyana, Pakaraima Mountains; LSUM, BRG. G. necrorhiza; HM136872,
_- _ - _ - ; MCA 2312; Guyana, Pakaraima Mountains; LSUM, BRG. G. necrorhiza; HM131826, HM131824, HM131826, HM131825, HM131819; TH 8989; Guyana, Pakaraima Mountains; HSU, BRG. G. necrorhiza; HM131822, —, HM131823, —, —; TH 9065; Guyana, Pakaraima Mountains; HSU, BRG. G. necrorhiza hyphal cord; - - HM131820, —, -; TH 9065R; Guyana, Pakaraima Mountains; HSU. G. necrorhiza mycelial fan; —, - , HM131821, —, —; TH 9065MF; Guyana, Pakaraima Mountains; HSU. Gymnopus contrarius (Peck) Halling; DQ457670, DQ440643, DQ486708, DQ472716,_. Halocyphina villosa Kohlm. \& E. Kohlm.; AF426957, AF426951, AY571042, —, —. Lachnella villosa (Pers.) Gillet; DQ097362, AY70595, DQ097362, DQ472732, —. Lentinula lateritia (Berk.) Pegler; AF287872, AF026596, U33070, AY218492, —. Marasmius rotula (Scop.) Fr.; DQ457686, DQ113912, DQ182506, DQ474118, - . Mycaureola dilseae Maire \& Chemin; DQ097348, DQ097342, DQ097364, -, - Mycotribulus mirabilis Nag Raj \& W.B. Kendr.; EF489740, —, —, - , —. Nia vibrissa R.T. Moore \& Meyers; AF334750, AF334754, AY571053, DQ408111, —. Oudemansiella canarii (Jungh.) Höhn.; AF261351, —, —, —. Oudemansiella mucida (Schrad.) Höhn.; AY207260, —, —, -, —. Oudemansiella radicata (Relhan) Singer; DQ071719, _, —, DQ029194. Physalacria bambusae Höhn.; DQ097349, AY705953, DQ097367, DQ474123, - Physalacria corticola Corner; DQ284913, - , -, - - - Physalacria inflata (Schwein.) Peck; DQ284915, - , - , - - . Physalacria maipoensis Inderb. \& Desjardin; AF426959, AF426953, —, - Porodisculus pendulus (Schwägrichen \{?\}) Schwein.; AY293204, AY293150, AY572009, - - - Rhodotus palmatus (Bull.) Maire; AF042565, —, - , - - - Schizophyllum commune Fr.; AF334751, X54865, AF249390, AY218515, X94913. Schizophyllum radiatum (Sw.) Fr.; AY571023, AY705952, AY571060, DQ484052, —. Strobilurus esculentus (Wulfen) Singer; AM946468, - - - - - - Strobilurus stephanocystis (Kühner \& Romagn. ex Hora) Singer; AM96469, —, - , -, - Strobilurus tenacellus (Pers.) Singer; AM946470, —, - , 一, Xerula furfuracea (Peck) Redhead, Ginns \& Shoemaker; AY691890, DQ089015, DQ494703, —, —. Xerula megalospora (Clem.) Redhead, Ginns \& Shoemaker; AF042649, - , 一, - - - Xerula radicata (Relhan) Dörfelt; AY645051, AY654884, DQ241780, AY786067, —. 